\title{
ATHENA'S BIRTH ON THE NIGHT OF THE DARK MOON
}

\author{
CATALIN ANGHELINA \\ The Ohio State University/University of Bucharest*
}

\begin{abstract}
The exact days on which the Panathenaia was celebrated are not altogether clear, with the exception of Hekatombaion 28 (I 28), the day of the great $\pi \circ \mu \pi \eta$ honouring Athena. In two ancient scholia it is said that Athena's birthday was celebrated on this main day of the festival. This information has often been deemed false, owing to the existence of other, conflicting testimony according to which Athena's birthday was celebrated on the third of each month, a fact seemingly in accord with her epithet of Tritogeneia. The association between I 28 and Athena's birthday has been

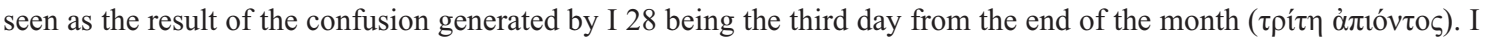
argue that the information contained in the scholia is not the result of confusion. Athena's birthday was indeed celebrated on the main day of the Panathenaia. This date was set in stone by Pheidias on the Parthenon's east pediment.
\end{abstract}

Keywords: Athena's birthday, dark moon, Parthenon sculptures, Parthenon east pediment, Selene

The festival of the Panathenaia was the most important religious celebration in ancient Athens. As is well known, it occurred in two forms: a regular annual festival, the Lesser Panathenaia, and, every four years, a more grand and spectacular celebration, the Great Panathenaia. ${ }^{1}$ It is not altogether clear which were the exact days of the festival. What we know is that the festival occurred towards the end of Hekatombaion, the first month (I) of the Attic calendar. More precisely, as two ancient sources, Proklos on Plato Timaeus $17 \mathrm{~b}$ and the scholiast to Plato Republic 327a, inform

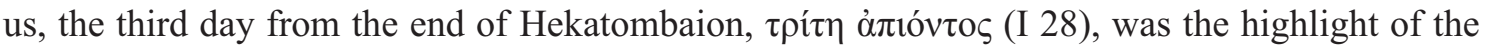
Great Panathenaia. ${ }^{2}$ This was the day of the huge Panathenaic pompê, whose culminating moment was the presentation of the sacred peplos to the ancient xoanon of Athena Polias in her temple on the Acropolis. ${ }^{3}$ The grand festival lasted several days. Two sources indicate the number of days of the Great Panathenaia as four. ${ }^{4}$ However, given the complexity and number of the musical, athletic and religious events of the festival (for example sacrifices, the great procession), it is conceivable that this number could even exceed four. ${ }^{5}$ There is, on the other hand, no clear evidence of the number of days of the Lesser Panathenaia. The little extant evidence points to a duration of few days, one or two at the most. No main day is indicated for the Lesser Panathenaia, though there is no reason to believe that this day was different from I $28 .^{6}$ There is also no precise information about whether the same type of peplos or even any peplos at all was offered to Athena Polias on the occasion of the Lesser Panathenaia in Classical times. ${ }^{7}$

\footnotetext{
* cangheli@cscc.edu. I would like to thank the JHS editor and reviewers for their suggestions for improving this paper. It goes without saying that any remaining errors belong only to me.

1 For the Panathenaia, see Mommsen (1898) 41-159; Deubner (1932) 22-35; Ziehen (1949); Davison (1958); Parke (1977) 33-50; Simon (1983) 55-72; Robertson (1985); Tracy (1991); Neils (1992); Shear (2001) 1-376; Parker (2005) 253-69; Connelly (2014) 247-93.

2 The 28th day of the month was called $\tau \rho i$ in

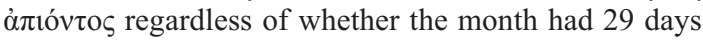
(hollow month) or 30 days (full month): see Samuel (1972) 61; see also below, for discussion.

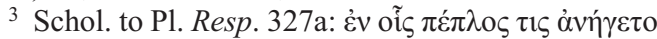

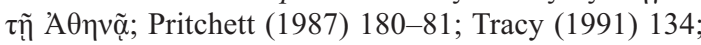

Shear (2001) 97-103, 173-86; Sourvinou-Inwood (2011) 264-70. By the end of the fifth century BC, the temple of Athena Polias was the Erechtheion; for a history of the different locations of the temples of Athena Polias on the Acropolis (for example the Archaios Neos), see Hurwit (1999) 200-02.

${ }^{4}$ Schol. to Aristid. 13 Panathenaikos 115.19, 147.9, 147.13 (Dindorf); schol. to Eur. Hec. 469 (Michaelis).

5 Such events are listed in $I G \mathrm{II}^{2} 2311$ (fourth century BC); Mommsen (1898) 153; Davison (1958) 24-25; Parke (1977) 35; Pritchett (1987) 181; Neils (1992) 15; Parker (2005) 256.

${ }^{6}$ Deubner (1932) 23.

7 Davison (1958) 24-26; Hurwit (1999) 45; Shear (2001) 98-102; Parker (2005) 268-69. 
The Panathenaic celebrations on I 28 lie at the origin of a controversial issue. Two sources give this date as Athena's birthday. ${ }^{8}$ In modern scholarship, this information has been deemed false. ${ }^{9}$ There are two main reasons behind this conclusion. First, the birthdays of the Olympian gods seem to have been tied to certain days of the month and not of the year. ${ }^{10}$ Further, these birthdays fell in the first decade of the month, not in the last one. Accordingly, Apollo's birthday was celebrated on the seventh of each month, Artemis' on the sixth, Hermes' and Aphrodite's on the fourth, etc. ${ }^{11}$ Second, there is information according to which Athena's birthday occurred on $\tau \rho \imath \tau$ p $\mu$ vís, the third of each month, a fact which seems to be in complete accord with the timing of the other divine birthdays celebrated in the Attic calendar. ${ }^{12}$ Given these considerations, the idea that Athena's birthday was celebrated on I 28 has been seen as the result of an erroneous connection between Athena's

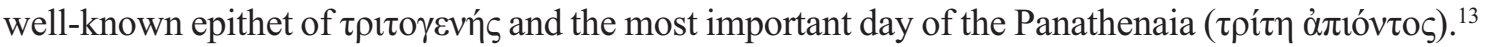

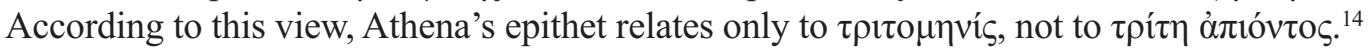

Athena's birthday could not be celebrated twice in the same month. The goddess' birthday must have been celebrated either on I 28 or on the third of each month. As noted above, the main argument for the latter date is the fact that other divine birthdays occurred during the first decade of the month. However, not all such days, on which certain gods were worshipped, represented their birthdays. The eighth of the month, for example, was a day sacred to Poseidon without representing his birthday. ${ }^{15}$ In many parts of the Greek world, Apollo was celebrated not only on the seventh of the month, his birthday, but also on the first day of the month, as Apollo Noumenios. ${ }^{16}$ Aside from the sixth of the month, Artemis was worshipped on the 16 th as well. ${ }^{17}$ Therefore, given the existence of two alternative explanations, there can still be no certainty that Athena's birthday occurred on the third of the month, and not on I 28. It is possible that the third of the month merely represents a day for worshipping Athena.

The arguments against the possibility that Athena's birthday was celebrated at the Panathenaia

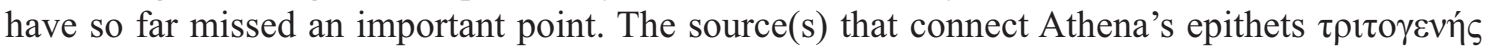
and Tritogeneia with I 28 do not merely count backwards three days from the end of this month. I 28 happens to be not just the third day before the end of the month but also the most important day of the Panathenaia. Assuming that Athena's birthday was not celebrated on I 28, it follows that the connection between Athena's epithets and this date, which represents the culmination of the festival, is purely coincidental. I 28 , however, is not a date that was randomly chosen to mark the most important day of the festival. ${ }^{18}$ In fact, this day has a marked astronomical significance.

It is well known that in historical times the Athenians, like the other Greeks, used a luni-solar calendar to keep track of time. This type of calendar takes into account both the cyclical phases of the moon and the movement of the sun in the sky during the year. ${ }^{19}$ According to this system of time measurement, the month starts on the evening of the first visible crescent in the western sky

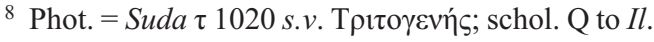
8.39; the first modern identification of the Panathenaia as a celebration of Athena's birthday was advanced by Preller and Robert (1894) 212, n. 2; cf. Deubner (1932); Parke (1977) 33; Pritchett (1987) 188; Shear (2001) 2930; Connelly (2014) 424, n.95.

9 Alternatively, sources from antiquity consider the aition of the Panathenaia to be related to: (1) Erichthonios; (2) the unification of Attica by Theseus; (3) Athena's role in the defeat of the giants by the gods (the Gigantomachy): Davison (1958) 24-25; Hurwit (1999) 30-31; Shear (2001) 31-71; Parker (2005) 254-56.

10 Mikalson (1975) 14; Parker (2005) 256.

11 Such birthdays were known to Hesiod (Op. 770 71, 800): Mikalson (1975) 16-19; Trümpy (1998) 109.

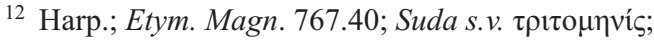
Mikalson (1975) 16.
13 Mommsen (1898) 158; Kruse (1939); Mikalson (1975) 23, 34; Kerényi (1978) 40-41; Pinney (1988) 471; Hurwit (1999) 44; Parker (2005) 256.

14 Tritogeneia was sometimes considered an obscure

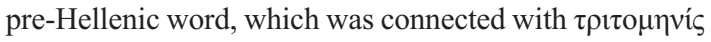
by false etymology: Kerényi (1978) 40.

15 Mikalson (1975) 19-20; the day was also sacred to Poseidon's son Theseus without being his birthday.

16 Detienne (1998) 56-57; Nilsson (1962) 38-40. Novunvía is the first day of the month, the day of the first visible crescent.

17 Mikalson (1975) 21; coincidentally or not, this is also the 'sixth day' of the second decade of the month.

18 Schmidt (1908) 99.

19 Pritchett and Neugebauer (1947) 3-7; Nilsson (1962) 44-51; Samuel (1972) 11-12, 19-64; Bickerman (1980) 27-38. 
at dusk. At the end of the month, after the crescent of the old moon is for the last time visible at dawn in the eastern sky, the moon becomes invisible for one to three nights. ${ }^{20}$ The invisibility of the moon is due to the fact that the moon is in direct alignment with the earth and the sun: the astronomical phenomenon called 'conjunction' ${ }^{21}$ The precise moment of the conjunction is not predictable without sophisticated calculations and it depends on many factors, such as the latitude of the observer, the time of the year and the distance between the moon and the earth. It can occur during the day or during the night. ${ }^{22}$ Given that the cycle of the moon takes, on average, 29.53 days, the number of days in a month of the Attic calendar was either 30 (full month) or 29 (hollow month). ${ }^{23}$ The Athenian year started on the evening of the first visible crescent of the new moon after the summer solstice. ${ }^{24}$ There is no general agreement among scholars whether the Greek calendar day started at sunset or at sunrise. ${ }^{25}$ Geminos states in the first century BC (Eisagoge 6.1) that for the Greeks a day 'is the time from sunrise to sunrise. ${ }^{26}$ For practical purposes, I use Geminos' referential system; this has no bearing on my arguments.

According to modern observations made in midsummer (July to August) in Athens, the time interval between conjunction and the visibility of the new crescent is longer than average and amounts to at least one and a half days. ${ }^{27}$ This means that, regardless of whether Hekatombaion was a hollow or a full month, I 28 was a conjunction day. In other words, the night of Hekatombaion 28 was moonless. The waning crescent of the 'old' moon was seen for the last time at the dawn of I 28 in the eastern sky. ${ }^{28}$ The new crescent reappeared in the western sky on the evening of either I 29 (hollow month) or I 30 (full month). ${ }^{29}$

These considerations reveal an important fact. Depending on how one interprets the epoch of the Greek calendar day, I 28, the main day of the Panathenaia, was either the day of the waning crescent or, from Geminos' perspective, the day of the dark moon. The importance of the crescent for the Panathenaia, which occurred precisely during the time of the waning moon, is well attested. The crescent appears on a large issue of Athenian coins, which has the head of Athena on the obverse and an owl standing on a Panathenaic amphora on the reverse. ${ }^{30}$ In a passage from Euripides' lost tragedy Erechtheus, King Erechtheus asks his wife Praxithea about the Panathenaic 'moon' cakes made from wheat. Since these cakes are especially made for the Panathenaia, they must point to the waning moon, the time of the festival. ${ }^{31}$ This association, then, between the Panathenaia and the crescent, raises a natural question. Was the reason for choosing I 28 as the main day of the Panathenaia related to the night of the last visible crescent, as Pritchett believes, or to the night of the dark moon that immediately followed? ${ }^{32}$

To answer this question, I turn now to Pheidias' set of sculptures depicting Athena's birth on the east pediment of the Parthenon. ${ }^{33}$

20 Geminos Eisagoge 9-14; Bickerman (1980) 18.

21 The period from conjunction to conjunction $(\mathrm{Gk}$ synodos) is called the synodic month or lunation; it can vary from 29.26 to 29.80 days due to the elliptical trajectories of the moon and earth: Pritchett (1959) 151; Samuel (1972) 5-7; Bickerman (1980) 18.

22 Samuel (1972) 8-10.

${ }^{23}$ Cf. n. 2; Pritchett and Neugebauer (1947) 5-6; Samuel (1972) 14.

24 Samuel (1972) 57; Bickerman (1980) 13-14.

25 This constitutes the vexed issue of the epoch of the Greek calendar day: see Meritt (1961) 16-17; van der Waerden (1960) 168-69, 176; Pritchett (1982) 262-63; (1987) 179; (1999) 87-89; Stern (2012) 26-27, n. 5.

${ }^{26}$ Cf. Plut. Sol. 25.4-5; Nilsson (1962) 16; Pritchett (1982) 248, 260-63; (1999) 85.
27 Ginzel (1906) 93; similar conclusions are established by Parker (1950) 1-12 for Egypt; $c f$. Pritchett (1959) 154.

28 Pritchett (1987) 183, n. 14; Kidd (1997) 576-77.

29 Pritchett (1987) 188.

${ }^{30}$ Head (1911) 370; Lacroix (1965); Pritchett (1987) 183.

31 Erechtheus fr. 350: 'And as you are bringing much sacred mixture from the house, tell me (why/where you are taking) these 'moons' made from young wheat ...': Collard and Cropp (2008) 371; cf. Connelly (1999) 280.

32 Pritchett (1987) 183 interprets the crescent on these coins as an indication of the arrival of I 28, Athena's birthday.

33 For the east pediment, see Carpenter (1933); Harrison (1967); Berger (1974); Brommer (1979) 52-58; Jeppesen (1984); Palagia (1993); Mostratos (2004). 
As there is not much left of the sculptures of the east pediment, it is impossible to reconstruct with precision the disposition of the sculpted figures or even their identity. If it were not for Pausanias' account, it would be impossible to know even the subject matter of Pheidias' work. In his brief account of the east pediment, Pausanias informs us that it represented the birth of Athena. ${ }^{34}$ Given the subject matter, there can be little doubt that the scene of Athena's birth, in which Zeus and Athena played the main roles, occupied the now lost central section of the pediment. The exact disposition of the characters in this scene is unknown. The several attempts that have been made to reconstruct this central section are based on deductions from other well-known artistic works such as the Roman puteal in Madrid or the early fourth-century red-figure krater from Baksy, and can offer no certainty about the actual configuration of the scene. ${ }^{35}$

Fortunately, the two sculptures at the northern and southern extremities of the east pediment survive. ${ }^{36}$ At the southern corner of the pediment, Helios in his quadriga emerges from the waves of Ocean, which are sculpted on the pediment. The heads and necks of Helios' horses point upwards, giving the impression that they rise from the horizontal cornice. There is little doubt that this sculpture symbolizes the sunrise. The identity of the female figure sculpted at the opposite northern corner of the pediment has, however, stirred controversy. Like Helios, this figure also drives a quadriga, but the direction of its movement is, in contrast to that of Helios, downwards. The horses, whose muzzles overhang the horizontal cornice, seem to sink into the pediment floor. The prevalent opinion among scholars is that this latter sculpture represents Selene, the natural counterpart to Helios in framing the cosmic event of Athena's birth. ${ }^{37}$ According to this view, the postures of Selene's horses would indicate her western setting in the Ocean. ${ }^{38}$ Thus, Athena's birth would have taken place at dawn, when Helios rises and Selene sets. ${ }^{39}$

This interpretation of the presences of Helios and Selene on the east pediment raises a huge problem. The only time within a month when the sun and the moon can be seen diametrically opposed in the sky, thus corresponding to their representations on the east pediment, is on the day of the full moon, when, indeed, the moon sets in the west exactly at sunrise. In the Greek calendar, this astronomical event occurs in the middle of the month. Therefore, according to this interpretation, one must assume that Athena's birthday occurred on the day of the full moon, in the middle of the month. ${ }^{40}$ There is, however, no evidence supporting such a conclusion; all the information we have points to Athena's birthday occurring either at the end or at the beginning of the month. This being the case, it is not possible to interpret the diametrically opposed figures of Helios and Selene on the east pediment as symbolizing Athena's birth on the day of the full moon.

To overcome these difficulties, it has been postulated that the enigmatic feminine figure at the northern end of the east pediment is Nyx. ${ }^{41}$ According to this theory, the sculptures of the east pediment depict only Athena's birth at dawn, as apparently indicated in a passage in the Homeric Hymn to Athena $28,{ }^{42}$ and the presence of the setting Nyx serves to reinforce the idea of dawn. This interpretation, however, is also problematic. First, there is no other evidence for Nyx being

${ }^{34}$ Paus. 1.24.5.

35 Roman puteal: Museo Arqueológico Nacional, Madrid, 2691; Baksy Krater: Hermitage Museum, St Petersburg, Baksy 8: Palagia (1993) 27-30; Shear (2001) 741; cf. Carpenter (1933) 34-44; Delivorrias (1982). 23.

${ }^{36}$ For their description, see Palagia (1993) 7-17, 18

37 Brommer (1979) 54 notes: 'No other version of the birth of Athena is framed in this particular way.'

${ }^{38}$ In contrast to the case of Helios, there are no visible 'waves' around Selene; Palagia (1993) 23 argues for their originally being part of the sculpture, filling the space between Selene and her chariot.
39 Brommer (1979) 52; Gury (1994) 710; Stewart (1990) 15-54; Palagia (1993) 18, 22; (2005) 234-36; Delivorrias (1994) 101-02; Hurwit (1999) 179; Lagerlöf (2000) 51-57; Jenkins (2007) 47; Beard (2010) 139; Connelly (2014) 103-04.

40 Nilsson (1962) 41; Neils (1993) 230; Palagia (1993) 18; Jeppesen (1984) 275

${ }^{41}$ Jeppesen (1984) 275; cf. Berger (1974) 13-14; Palagia (1993) 34, n. 77; Boardman and Finn (1985) 230.

${ }^{42}$ Hymn. Hom. Min. 28.12-16: 'The briny sea calmed down / when the splendid son of Hyperion stopped / his fleet-footed horses long enough for maidenly / Pallas Athena to take from her immortal shoulders / the divine weapons ...' (Athanassakis (1976)). 
associated with Helios in such a way. ${ }^{43}$ Nyx appears to be in opposition to Eos, not to Helios. ${ }^{44}$ Second, the passage in the Homeric Hymn does not in fact indicate that Athena's birth occurred at dawn. It states only that Helios stopped his horses long enough for Athena to take off her armour from her shoulders. This means that Athena's birth occurred before dawn, during a longer than usual period of darkness. ${ }^{45}$ Nyx, therefore, does not seem to be a better choice than Selene as the female figure at the northern end of the east pediment.

To work around this impasse, I return again to the Selene hypothesis, the rejection of which is based on the correct observation that the birth of Athena could not occur on the day of the full moon: the day the presence of both Helios and Selene at first suggest. ${ }^{46}$ There is, however, another way to interpret the presence of Selene on the pediment, one that is in complete accord with the information in the scholia about the date of Athena's birth (i.e. I 28).

There can indeed be little doubt that the way Helios and Selene are represented on the pediment indicates sunrise and moonset, respectively. And, given the relative positions of these two celestial bodies, there can also be no doubt that the moment expressed by them is that of the full moon. ${ }^{47}$ In spite of appearances, however, the symbolism of this representation is not that Athena's birth occurred at full moon. The placement of the scene of Athena's birth in the middle of the pediment, on the vertical axis that stands centrally between the diametrically opposed Helios and Selene, who are both located on the horizontal axis, indicates that this birth occurred during the other important point of reference of the lunar cycle: the time of the conjunction. ${ }^{48}$ This latter moment is in a strict relation to the full moon, since it occurs exactly in the middle of the interval determined by two consecutive full moons. The whole scene can be interpreted as indicating that Athena's birth regulates the cycle of the moon, which is determined by two essential points: the full moon and the conjunction. This unusual way of rendering this moment is obviously related to the impossibility of physically representing an 'absent object', which is, in this particular case, the moon during the conjunction. The artist's solution was to represent this moment through its opposite. ${ }^{49}$

The scene sculpted on the east pediment, therefore, confirms the information of the scholiasts that Athena's birthday was celebrated on I 28, the day of the dark moon. In the case of the east pediment, which represents the culmination of the entire sculptural programme of the Parthenon, Pheidias and the Athenian architects wanted to fix in stone not only the most important event celebrated at the Panathenaia, but also the precise astronomical moment of its occurrence. ${ }^{50}$

43 Brommer (1963) 156; Karasu (1984) 180.

44 Karasu (1984) 180, no. 3 (Attic black-figure lekythos; Helios is represented between Eos and Nyx, who are in opposition). For the fact that, unlike in the present case, Nyx is usually represented with wings, see Brommer (1963) 156-57; Karasu (1984) 180.

${ }^{45}$ Cf. Od. 23.241-46, in which Athena prevents Dawn's horses from coming up from the Ocean. Obviously, this action must take place before dawn.

46 Pollitt (1990), who argues that the sculptures of Helios and Selene merely reflect the rational cosmos of Anaxagoras; Hurwit (1999) 243, 355, n. 38; Ehrhardt (2004) 33-38. The positions of Helios and Selene, which clearly show them rising and setting, respectively, contradict this statement.

47 One of the JHS referees brings to my attention the well-known medallion sculptures of the sun (in quadriga) and the moon (in biga) on the eastern and western sides, respectively, of the Arch of Constantine (AD 315), which are similar to those of the Parthenon. S/he raises the question whether these sculptures point to the full moon as well. Given the role of the full moon in the celebration of Christianity's main festival, Easter, this seems to be the case. The Council of Nicaea (AD 325) decided that this celebration should take place on the Sunday following the first full moon after the spring equinox. Before the Council of Nicaea, many Christians, following Jewish custom, even celebrated the Passover on the day of the full moon of that month (14 Nissan): see Euseb. Hist. eccl. 5.23. If this hypothesis is correct, then, aside from the well-known mysterious inscription on the arch's attic (instinctu diuinitatis), these sculptures represent the only other allusion to Christianity on the arch: Barnes (2011) 18-20, 120-26.

48 In modern scientific atlases, the new moon and the full moon are often represented on separate axes, which are perpendicular; $c f$., for example The Oxford Atlas of the World (2015) 73.

${ }^{49}$ From this standpoint, I would not completely rule out the Nyx hypothesis. Her unusual presence on the pediment as the counterpart of Helios could be interpreted as hinting to the absence of Selene from the sky on the night of the dark moon.

50 Several attempts have also been made to relate the Parthenon's orientation (northeast to southwest) to astronomical events, such as sunrise on the foundation date 
The way Selene is represented by Pheidias on the east pediment is peculiar in another respect. In Pheidias' other complex statuary groups, Helios and Selene also frame the subject matter of the whole composition. ${ }^{51}$ In these works, however, Selene is shown riding a horse or mule, and not driving a quadriga. ${ }^{52}$ This latter representation of Selene exists before Pheidias, ${ }^{53}$ and it remains very popular after him..$^{54}$ Pheidias must have had a reason to represent Selene on the east pediment driving a quadriga. Indeed, there is strong evidence that Pheidias' peculiar choice is not random. The fact that Selene drives a chariot at full moon is clearly attested in both Greek literature and art before Pheidias. ${ }^{55}$ This corroborates my interpretation that the sculpture of Selene on the east pediment symbolizes the full moon. ${ }^{56}$

Athena's birthday, therefore, occurred on the calendar day of the dark moon. ${ }^{57}$ This must be the reason why I 28 was the main day of the Panathenaia. Given that the phenomenon of the dark moon is noticeable only during night-time, it is legitimate to ask the more precise question of whether Athena's birth occurred on the night of I 28, and not during daytime. The existence of the Panathenaic pannychis, the night festival during which young boys and girls honoured Athena with songs and hymns ( $c f$. Eur. Heracl. 777-83), may point to this conclusion. ${ }^{58}$ As yet, there has been no certainty as to whether the festival occurred on the night of I 28 or on the night before (i.e. on I 27 according to Geminos' referential system). ${ }^{59}$ The conclusion of this paper provides an answer to this issue. Given that the celebrations honouring Athena Polias ( $c f$. n. 3), which included the offering of the peplos to the goddess, occurred at dawn on I 28, then Athena's birth in full armour must have occurred the night before, that is, before, as it is clearly said in the Homeric Hymn, she

or the appearance of certain stars in a particular festival season: Boutsikas (2011); Hannah (2013); Pantazis (2014). I suggest this orientation is related to the Panathenaia being celebrated during the time of the year when sunrise occurs from the northeast in general (July/August).

51 Helios and Selene frame: (1) 'Pandora's birth' on the base of the statue of Athena Parthenos in the Parthenon (reconstruction based on a Roman copy, the 'Lenormant Athena' (Athens, National Museum 128): Plin. HN. 36.18-19; Paus. 1.24.7; Leipen (1971) 24-26; Demargne (1984) 977; Gury (1994) 709, no. 37, Oppermann (1994) 164-65; Hurwit (1999) 26, 188; Shear (2001) 763; Kosmopoulou (2002) 114; Robertson (2004) 91-92; (2) the Ilioupersis on the north metopes (1-29) of the Parthenon: Brommer (1979) pls 44-45; Dörig (1984) 202-03; Berger (1986) 12, 14, 45-46; Gury (1994) 709, no. 38; for other possibilities (for example Nyx or Athena instead of Helios) for metope 1, see Berger (1986) 19; Shear (2001) 730; Schwab (2005) 188, 196, n. 4; and (3) the 'birth of Aphrodite' on the base of the statue of Zeus at Olympia: Paus. 5.11.8; Gury (1994) 709, no. 37; cf. Ehrhardt (2004) 3-7. This type of representation was called 'a Pheidian motif': Leipen (1971) 24; Robertson (2004) 91-92; Ehrhardt (2004) 33.

52 Selene (with crescent on her head), however, is shown riding a quadriga on a fourth-century Apulian redfigure krater in the Dallas Museum of Art (http://www.theoi.com/Gallery/T18.4.html).

${ }^{53}$ See the Attic red-figure vase from Orvieto (460 BC); $A R V^{2}$ 874, 4; Gury (1994) 709, 714, no. 35. This representation must be related to the well-known fact that the moon apparently moves slower than the sun in the sky. The moon is 'carried' by a single horse or a biga, and not by a quadriga like the sun.
54 Gury (1994) 709-12 (especially 709, no. 38 for Selene velificans - the other phases of the moon?); Karusu (1984) 916-17, 926; see also Savignoni (1899). In Aratus Phaen. 737 the full moon is described as $\pi \alpha v \tau \grave{\imath}$ $\pi \rho \circ \sigma \omega \pi \omega$, 'with full face'.

55 Pind. Ol. 3.18-19; Hymn. Hom. Sel. 32.10-12; for art examples (Greek vases from the first quarter of the fifth century BC), in which Selene rides a chariot (biga) and has a full disc on her head, see Karusu (1984) 912, 914,916 , nos 39, 59, 60. There is no extant evidence of Selene having the full disc on her head when she rides a horse.

56 In the case of north metope 29, Selene on a horse might represent the waning moon. Indeed, there is strong evidence that Troy fell during the waning moon: schol. Eur. Hec. 910 (the moon is rising at midnight, not at sunset); cf. Grafton and Swerdlow (1986). There is no evidence that the births of Aphrodite or Pandora occurred on nights of full moon. Ehrhardt (2004) 33-38 argues against attributing any temporal meaning to these scenes; he does not, however, explain why Helios, for example, is clearly shown rising on the east pediment.

57 This raises the possibility that both Athena's $\tau \rho ı$ o $\mu \eta v i s$ and the epithet of Tritogeneia derive from her

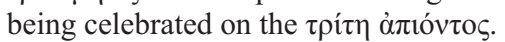

58 Pritchett (1987) 182; Parker (2005) 257; pannychides are attested for other festivals as well; Parker (2005) 166.

${ }^{59} I G \mathrm{II}^{2} 334.30,32-34$; in favour of the night of I 27 (before the $\pi \circ \mu \pi \eta$ ), see Deubner (1932) 24; Parke (1977) 49; Burkert (1985) 232; Tracy (1991) 133; Connelly (2014) 263-69; in favour of the night of I 28 (after the $\pi \circ \mu \pi \eta$ ), see Pritchett (1987) 181-82, 188; Shear (2001) 83-84; Connelly (2014) 422, n. 61; cf. Parker (2005) 257. 
took off the armour from her shoulders. This night, then, which must have been, at least from time to time, moonless as well, ${ }^{60}$ must have belonged to I 28 . This means that the epoch of the calendar day in Classical times must have been sunset, and not sunrise as in Geminos' time. The reason for the pannychis, therefore, must have been Athena's birth on the first night of the dark moon. ${ }^{61}$ As for the placement of this birth on such a night, this might be related to Athena's role as goddess of wisdom. Like her bird, the owl, Athena has the ability to 'see' in 'total darkness. ${ }^{62}$

\section{Bibliography}

Athanassakis, A.N. (1976) The Homeric Hymns (Baltimore)

Barnes, T. (2011). Constantine: Dynasty, Religion and Power in the Later Roman Empire (Chichester)

Beard, M. (2010) The Parthenon (Cambridge)

Berger, E. (1974) Die Geburt der Athena im Ostgiebel des Parthenon (Basel)

- (1986) Der Parthenon in Basel: Dokumentation zu den Metopen 1 (Mainz)

Bickerman, E.J. (1980) Chronology of the Ancient World (Ithaca)

Boardman, J. and Finn, D. (1985) The Parthenon and its Sculptures (London)

Boutsikas, E. (2011) 'Astronomical evidence for the timing of the Panathenaia', AJA 115.2, 303-09

Brommer, F. (1963) Die Skulpturen der Parthenon-Giebel 1 (Mainz)

- (1979) The Sculptures of the Parthenon: Metopes, Frieze, Pediments, Cult Statue (London)

Burkert, W. (1985) Greek Religion (Cambridge MA)

Carpenter, R. (1933) 'The lost statues of the east pediment of the Parthenon', Hesperia 2.1, 1-88

Collard, C. and Cropp, M. (eds) (2008) Euripides 7: Fragments (Cambridge MA)

Connelly, J.B. (1999) Portrait of a Priestess: Women and Ritual in Ancient Greece (Princeton)

- (2014) The Parthenon Enigma (New York)

Davison, J. (1958) 'Notes on the Panathenaea', JHS 78, 23-42

Delivorrias, A. (1982) 'Zum Problem des Zeus im Ostgiebel des Parthenon', in B. von Freytag gen. Löringhoff, D. Mannsperger, F. Prayon (eds), Praestant Interna: Festschrift für Ulrich Hausmann (Tübingen) 41-51

- (1994) 'The sculptures of the Parthenon', in P. Tournikiotis (ed.), The Parthenon and its Impact in Modern Times (Athens) 98-135

Demargne, P. (1984) 'Athena', LIMC 2.1 (Zurich and Munich) 955-1044

Deubner, L. (1932) Attische Feste (Berlin)

Detienne, M. (1998) Apollon le couteau à la main (Paris)

Dörig, J. (1984) 'Les métopes nord du Parthénon', in E. Berger (ed.), Parthenon-Kongress Basel: Referate und Berichte, 4. bis 8. April 1982 (Mainz) 202-05

Ehrhardt, W. (2004) 'Zu Darstellung und Deutung des Gestirngötterpaares am Parthenon', JDAI 119, 1-39

Ginzel, F.K. (1906) Handbuch der mathematischen und technischen Chronologie 1 (Leipzig)

Grafton, A.T. and Swerdlow, N.M. (1986) 'Greek chronography in Greek epic: the calendrical date of the fall of Troy in the Aeneid', CQ 36, 212-18

Grand-Clement, A. (2010) 'Dans les yeux d'Athéna Glaukôpis', Archiv für Religionsgeschichte 12, 7-22

Gury, F. (1994) 'Selene', LIMC 7.1 (Zurich and Munich) 706-15

Hannah, R. (2013) 'Greek temple orientation: the case of the older Parthenon in Athens', Nexus Network Journal 15, 423-43

Harrison, E.B. (1967) 'Athena and Athens in the east pediment of the Parthenon', AJA 71.1, 27-58

${ }^{60}$ For this possibility, see Aratus Phaen. 1150; $c f$. Kidd (1997) 576.

61 The 'longer night' described in the Homeric Hymn might refer to the absence of moonlight. Similarly, the Gigantomachy also took place on a moonless night: Apollod. Bibl. 1.6.1; Pinney (1988) 474.

${ }^{62} C f$. Athena's epithet $\gamma \lambda \alpha v \kappa \tilde{\omega} \pi \mathrm{s}$ : Leumann (1950) 148-54; Grand-Clement (2010). One should also note that Athena's role as a goddess of war corresponds with the owl being a notorious bird of prey. Interestingly, Athena's other companion, the serpent, which can also be a symbol of wisdom ( $c f$. Matt. 10.16), can be $\gamma \lambda \alpha v \kappa \tilde{\omega} \pi 1 \varsigma$ as well: Pind. Pyth. 4.249; Grand-Clement (2010) 18. This symbolism of the serpent (i.e. both wisdom and war) may also be reflected in the well-known representations of the Athenian kings with serpent bodies. 
Head, B.V. (1911) Historia Numorum (Oxford)

Hurwit, J.M. (1999) The Athenian Acropolis: History, Mythology, and Archaeology from the Neolithic Era to the Present (Cambridge)

Jenkins, I. (2007) The Sculptures of the Parthenon (Cambridge MA)

Jeppesen, K.K. (1984) 'Evidence for the restoration of the east pediment reconsidered', in E. Berger (ed.), Parthenon-Kongress Basel: Referate und Berichte, 4. bis 8. April 1982 (Mainz) 267-77

Karusu, S. (1984) 'Astra', LIMC 2.1 (Zurich and Munich) 904-27

Kerényi, K. (1978) Athene: A Study of Pallas Athene. Virgin and Mother (Zurich)

Kidd, D. (1997) Aratus: Phaenomena (Cambridge)

Kosmopoulou, A. (2002) The Iconography of Sculptured Statue Bases in the Archaic and Classical Periods (Madison)

Kruse, G. (1939) 'Tritogeneia', RE 7A.1 (series altera) (Stuttgart) 244-45

Lacroix, L. (1965) 'La chouette et le croissant sur les monnaies d' Athènes', AC 34, 130-43

Lagerlö, M.R. (2000) The Sculptures of the Parthenon: Aesthetics and Interpretation (New Haven)

Leipen, N. (1971) Athena Parthenos: A Reconstruction (Ontario)

Leumann, M. (1950) Homerische Wörter (Basel)

Meritt, B.D. (1961) The Athenian Year (Berkeley and Los Angeles)

Mikalson, J.D. (1975) The Sacred and Civil Calendar of the Athenian Year (Princeton)

Mommsen, A. (1898) Feste der Stadt Athen im Altertum (Leipzig)

Mostratos, G. (2004) 'A reconstruction of the Parthenon's east pediment', in M.B. Cosmopoulos (ed.), The Parthenon and its Sculptures (Cambridge) 114-49

Neils, J. (1993) Goddess and Polis: The Panathenaic Festival in Ancient Athens (Princeton)

Nilsson, M.P. (1962) Die Entstehung und religiöse Bedeutung des griechischen Kalenders (Lund)

Oppermann, M. (1994) 'Pandora', LIMC 7.1 (Zurich and Munich) 163-66

Palagia, O. (1993) The Pediments of the Parthenon (Leiden, New York and Cologne)

- (2005) 'Fire from heaven: pediments and akroteria of the Parthenon', in J. Neils (ed.), The Parthenon: From Antiquity to the Present (Cambridge) 225-60

Pantazis, G. (2014) 'The symmetric placing and the dating of the Parthenon and Hephaisteion in Athens (Greece)', Mediterranean Archaeology and Archaeometry 14.2, 273-79

Parke, H.W. (1977) Festivals of the Athenians (Ithaca)

Parker, R. (2005) Polytheism and Society at Athens (Oxford)

Parker, R.A. (1950) The Calendars of Ancient Egypt (Chicago)

Pinney, G.F. (1988) 'Pallas and Panathenaea', in J. Christiansen and T. Melander (eds), Ancient Greek and Related Pottery (Copenhagen) 465-77

Pollitt, J.J. (1990) 'The meaning of Pheidias' Athena Parthenos', in B. Tsakirgis and S.F. Wiltshire (eds), The Nashville Athena: A Symposium, 21 May 1990 (Nashville) 21-23

Preller, L. and Robert, C. (1894) Griechische Mythologie 1: Theogonie und Götter (4th edition) (Berlin)

Pritchett, W.K. (1959) 'The Athenian lunar month', CPh 54, 151-57

- (1982) 'The calendar of the gibbous moon', ZPE 49, 243-66

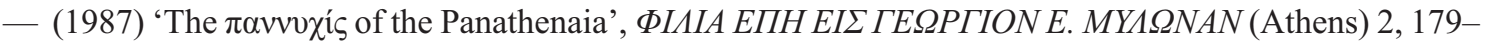
88

- (1999) 'The Athenian calendars', ZPE 128, 79-93

Pritchett, W.K. and Neugebauer, O. (1947) The Calendars of Athens (Cambridge)

Robertson, N. (1985) 'The origin of the Panathenaea', RhM 128, 231-95

- (2004) 'Pandora and the Panathenaic peplos', in M.B. Cosmopoulos (ed.), The Parthenon and its Sculptures (Cambridge) 86-113

Samuel, A.E. (1972) Greek and Roman Chronology (Munich)

Savignoni, L. (1899) 'On representations of Helios and of Selene', JHS 19, 265-72

Schmidt, W. (1908) Geburtstag im Altertum (Giessen)

Schwab, K.A. (2005) 'Celebrations of victory: the metopes of the Parthenon', in J. Neils (ed.), The Parthenon: From Antiquity to the Present (Cambridge) 159-98

Shear, J.L. (2001) Polis and Panathenaia: The History and Development of Athena's Festival (PhD Diss. Pennsylvania)

Simon, E. (1983) Festivals of Attica (Madison) 
Sourvinou-Inwood, C. (2011) Athenian Myths and Festivals: Aglauros, Erechtheus, Plynteria, Panathenaia, Dionysia (Oxford)

Stern, S. (2012) Calendars in Antiquity: Empires, States and Societies (Oxford)

Stewart, A. (1990) Greek Sculpture: An Exploration 1 (New Haven)

Tracy, S.V. (1991) 'The Panathenaic festival and games: an epigraphic inquiry', Nikephoros 4, 133-53

Trümpy, C. (1998) 'Feste zur Vollmondszeit: die religiösen Feiern Attikas im Monatslauf und der vorgeschichtliche attische Kultkalender', ZPE 121, 109-15

van der Waerden, B.L. (1960) 'Greek astronomical calendars and their relation to the Athenian civil calendar', JHS 80, 168-80

Ziehen, L. (1949) 'Panathenaia', RE 18.3, 457-89 (Stuttgart) 